\title{
As consequências do etnocentrismo de Olavo de Carvalho na produção discursiva das novíssimas direitas conservadoras brasileiras
}

\author{
Pablo Ornelas Rosa ${ }^{1}$ \\ Rafael Alves Rezende ${ }^{2}$ \\ Victória Mariani de Vargas Martins ${ }^{3}$
}

\begin{abstract}
Resumo: $\mathrm{O}$ artigo apresentado resulta de uma pesquisa desenvolvida a partir da utilização do método cibercartográfico que visou analisar os impactos dos discursos proferidos por Olavo de Carvalho nos comportamentos e narrativas produzidas por grupos políticos que estamos chamando de novíssimas direitas a partir do entendimento de Richard Day acerca dos novíssimos movimentos sociais que, em um contexto de emergência daquele verbete que o dicionário Oxford chamou em 2016 de pós-verdade, passou a intensificar muito mais o formato do que o conteúdo das informações que circulam pela internet. $\mathrm{O}$ ponto de partida de nossa análise decorre da constatação de certa leitura etnocêntrica encontrada tanto nas análises de Olavo de Carvalho quanto de seus seguidores que atuam como digital influencers, difundindo informações equivocadas, mentiras ou mesmo distorcendo fatos que reiteram aquilo que a analítica foucaultiana chamou de racismo de Estado.
\end{abstract}

Palavras-chaves: pós-verdade, direita, conservadorismo, ursal.

\section{The consequences of Olavo de Carvalho's ethnocentrism in the discoursive production of the newest Brazilian conservative right}

\footnotetext{
${ }^{1}$ Pablo Ornelas Rosa é doutor em ciências sociais pela Pontifícia Universidade Católica de São Paulo PUC/SP (2012) com estágio pós-doutoral em sociologia pela Universidade Federal do Paraná - UFPR (2014) e em saúde coletiva pela Universidade Federal do Espírito Santo - UFES (2018), mestre em sociologia política (2008) e bacharel em ciências sociais (2005) pela Universidade Federal de Santa Catarina - UFSC. Professor permanente nos Programas de Pós-Graduação em Sociologia Política PPGSP (Mestrado Acadêmico) e em Segurança Pública - PPGSO (Mestrado Profissional) da Universidade Vila Velha - UVV e coordenador do Grupo de Pesquisa em Subjetividade, Poder e Resistência - GESPOR.

${ }^{2}$ Rafael Alves Rezende é mestre em estudos literários pela Universidade Federal do Espírito Santo UFES, graduado em ciências sociais pela Universidade de São Paulo - USP e atua como professor de sociologia, antropologia, ciência política, filosofia e ética na Universidade Vila Velha - UVV, além de ser integrante do Grupo de Pesquisa sobre Subjetividade, Poder e Resistências - GESPOR.

${ }^{3}$ Victória Mariani de Vargas Martins é estudante do curso de graduação em jornalismo da Universidade Vila Velha - UVV e integrante do Grupo de Pesquisa sobre Subjetividade, Poder e Resistências GESPOR.
} 


Abstract: The article presents the results of a research that used cybermapping
to analyse the impact of Olavo de Carvalho's discourses on behavior
types and the narratives produced by political groups we rall
'newest right' based on our understanding of Richard Day's writing
on newest social movements which, in the wake of the adding of the
post-truth entry to the Oxford the Dictionary in 2016 started to
intensify the format rather than the content of the information that
is spread across the Internet. The analysis departs froms from an
observation of an ethnocentric reading both of Olavo de Carvalho's
analysis and his followers who work as digital influencers, spread
misleading information and lies, and distort facts that reinforce what
Foucault called State racism.

Key words: post-truth, rigth, conservatism, ursal.

\section{Ponderações iniciais}

O artigo apresentado foi construído a partir da utilização de uma metodologia que estamos chamando de cibercartografia política, baseada, sobretudo, na tradição pós-estruturalista, uma vez que considera e aproveita todas as possibilidades de obtenção de elementos discursivos, independente de seus formatos, métodos, técnicas, tecnologias e mecanismos de produção de narrativas. Todavia, foi por meio desta estratégia que conseguimos obter relatos e discursos que possivelmente não seriam localizados de um modo tão particular, justamente porque parte deles foi retirado das redes virtuais e canais visitados neste ciberespaço aonde são produzidos e difundidos os seus conteúdos, além das perspectivas extraídas das referências bibliográficas utilizadas.

Apesar da existência de outro método também chamado cibercartográfico, conforme foi exposto inicialmente por Fraser Tylor (2014), mas que não se baseia necessariamente em um ponto de vista genealógico nietzscheano sustentado nos escritos de Michel Foucault, Gilles Deleuze, Félix Guattari, Suely Rolnik, dentre outros autores fundamentais para tratar da complexidade dos conteúdos que circulam pela internet produzidos por certos grupos conservadores; adotaremos uma perspectiva pósestruturalista apostando na investigação das mais distintas formas de produção de análises e extração de informações para além das capturas que se dão em um nível meramente moral. 
O princípio/antiprincípio do cartógrafo o protege da captura pela moral. A análise do desejo assim concebida é, fundamentalmente, uma ética. Explico: se o cartógrafo nada tem a ver com os mundos que se criam (que conteúdos, que valores, que línguas) - a questão moral -, ele tem, e muito, a ver com o quanto a vida que se expõe à sua escuta se permite passagem; com o quanto os mundos que essa vida cria têm como critério sua passagem. Aqui, há uma questão ética. Em outras palavras: se não cabe ao analista do

desejo sustentar valores, não é por isso que não lhe cabe sustentar coisa alguma. (Rolnik, 2007, p. 70)

Embora utilizemos o método cartográfico apresentado por Rolnik (2007) para situar o que estamos chamando de cibercartografia política das novíssimas direitas conservadoras brasileiras, ainda o posicionamos em um certo lugar e com uma determinada particularidade espacial, só possível de ser capturada no ciberespaço. É justamente por isso que, além de usarmos os textos produzidos em formato de livro e/ou artigos, também utilizamos esse método no contexto das virtualidades geradas pela internet e de seus desdobramentos no campo da política institucional, sobretudo, no que se refere à busca pelos valores compartilhados pelas direitas conservadoras orientadas a partir daquilo que Richard Day $(2005$; 2016) chamou de novíssimos movimentos sociais, visando ponderar sobre os seus discursos através de narrativas construídas por autores como Mario Ferreira dos Santos (2012) e, principalmente, Olavo de Carvalho $(2012 ; 2014 ; 2018)$ - e seus alunos conservadores que o consideram o maior filósofo do país - por meio de vídeos gerados e difundidos por diferentes sujeitos e grupos que reproduzem suas visões de mundo, reiterando, portanto, certa cosmologia conservadora, cristã, colonizadora e ocidêntica encontrada nas supostas teorias acerca do que tem sido chamado de Nova Ordem Mundial, globalismo e guerras culturais.

Contudo, apesar dessas pautas terem sido registradas e difundidas em um contexto precedente à emergência da pós-verdade, estabelecida como palavra do ano pelo Dicionário Oxford em $2016^{4}$, acreditamos que a abordagem apresentada por

\footnotetext{
${ }^{4}$ https://brasil.elpais.com/brasil/2016/11/16/internacional/1479308638_931299.html Acesso em 27 de julho de 2018.
} 
Richard Day (2005; 2016) tenha nos permitido encontrar algumas características particulares do conservadorismo brasileiro nos princípios do século XXI através do que estamos chamando de novíssimas direitas conservadoras, considerando a relevância, mas também distinguindo do que Antônio Flávio Pierucci (2000) chamou de novas direitas, ao tratar daqueles grupos políticos que vivenciaram os primeiros anos da redemocratização no Brasil a partir da década de 1990.

Portanto, a cibercartografia política, que orienta a nossa investigação acerca das novíssimas direitas conservadoras, se deu por meio de uma construção teórica de inspiração pós-estruturalista sustentada por uma perspectiva genealógica, mas que foi trazida inicialmente por Fraser Taylor (2014), compreendendo a organização, apresentação, análise e comunicação da informação espacialmente utilizada como referência de um ponto de vista multidisciplinar tratada de maneira interativa, dinâmica e multisensorial decorrente da utilização de interfaces multimídia e multimodal. Nesse sentido,

\begin{abstract}
Genealogia quer dizer ao mesmo tempo valor da origem e origem dos valores. Genealogia se opõe ao caráter absoluto dos valores tanto quanto a seu caráter relativo ou utilitário. Genealogia significa o elemento diferencial dos valores do qual decorre seu próprio valor. Genealogia quer dizer, portanto, origem ou nascimento, mas também diferença ou distância na origem. Genealogia quer dizer nobreza e baixeza, nobreza e vilania, nobreza e decadência na origem. $\mathrm{O}$ nobre e o vil, o alto e o baixo: eis o elemento propriamente genealógico ou crítico. Mas, assim compreendida, a crítica é ao mesmo tempo o que há de mais positivo. $\mathrm{O}$ elemento diferencial não è critico do valor dos valores, sem ser também o elemento positivo de uma criação. Por isso a crítica nunca è concebida em Nieztsche como uma reação, mas sim como uma ação. (Deleuze, 2018, p. 10-11)
\end{abstract}

Sendo assim, investigaremos as novíssimas direitas conservadoras não apenas sob uma perspectiva epistemológica encontrada nos escritos de Nietzsche (2009), mas principalmente sob a ótica de autores como Foucault, Deleuze, Guattari e Rolnik; como também analisaremos genealogicamente a construção discursiva destes grupos a partir de ponderações trazidas pela antropologia social, principalmente através dos estudos de Clifford Geertz (2004) sobre o islamismo no Marrocos e na Indonésia, assim como utilizaremos as análises de Claude Levi-Strauss (1985) acerca de seu entendimento sobre raça e cultura, tendo em vista que encontramos nas narrativas de Olavo de 
Carvalho (2012; 2014; 2018) e sua referência Mario Ferreira dos Santos (2012), assim como no texto de seu aluno Alexandre Costa (2015), bem como nos vídeos de seus seguidores que atuam como digital influencers em canais da internet, algumas ponderações resultantes de certos determinismos que comprometem todo o caráter científico de seus posicionamentos, já que confunde o ententimento tanto acerca da noção de ciência quanto de cultura, através de um olhar situado a partir do que poderíamos tratar como etnocentrismo, conforme nos mostra Lévi-Strauss (1985), ao argumentar que

\begin{abstract}
A atitude mais antiga e que repousa, sem dúvida, sobre fundamentos psicológicos sólidos, pois que tende a reaparecer em cada um de nós quando somos colocados numa situação inesperada, consiste em repudiar pura e simplesmente as formas culturais, morais, religiosas, sociais e estéticas mais afastadas daquelas com que nos identificamos. "Costumes de selvagem", "isso não é nosso", "não deveríamos permitir isso", etc., um sem número de reações grosseiras que traduzem este mesmo calafrio, esta mesma repulsa, em presença de maneiras de viver, de crer ou de pensar que nos são estranhas. Deste modo a Antiguidade confundia tudo que não participava da cultura grega (depois greco-romana) sob o nome de bárbaro; em seguida, a civilização ocidental utilizou o termo de selvagem no mesmo sentido. Ora, por detrás destes epítetos dissimula-se um mesmo juízo: é provável que a palavra bárbaro se refira etimologicamente à confusão e à desarticulação do canto das aves, opostas ao valor significante da linguagem humana; e selvagem, que significa "da floresta", evoca também um gênero de vida animal, por oposição à cultura humana. Recusa-se, tanto num como noutro caso, a admitir a própria diversidade cultural, preferindo repetir da cultura tudo o que esteja conforme à norma sob a qual se vive. (Lévi-Straus, 1985, p. 53)
\end{abstract}

Apesar de a cartografia não ser um método formulado pela analítica foucaultiana, mas por Deleuze e Guattari, também através das análises de Foucault e de seu olhar acerca das perspectivas apresentadas por Niezsche (2009), é importante mencionar que os agenciamentos coletivos de enunciação nestes espaços virtuais, que têm se dado principalmente por estratégias de marketing no contexto da pós-verdade, conseguiram fazer com que o conteúdo das informações produzidas e circuladas pela internet passasse a ser substituído pela forma e formato difundidos por programas disponiblizados no facebook, youtube, instagram, dentre outros, que conseguem um alcance enorme se comparado à difusão dos conteúdos produzidos e difundidos pelas universidades e demais espaços científicos. 
Diante disso, constatamos um aumento e até proliferação de informações distorcidas ou mesmo equivocadas operadas a partir de uma perspectiva utilitária, antiesquerdista, ani-gênero, etc., que estabelece arbitrarimente os valores ocidentais como os únicos pressupostos da existência de certa humanidade supostamente "civilizada", definindo como inimigos todos aqueles que questionam quaisquer dimensões de mudanças acerca daquilo que entendem como o comportamento mais adequado para os indivíduos e sociedades, amparadas, sobretudo, em certa idealização saudosista baseada na perpetuação do entendimento filosófico e democrático encontrado na construção caricatural da democracia grega, do direito romano e, em especial, dos valores abalizados pela tradição judaico-cristã. Entretanto, é importante mencionar que "Todo sistema cultural tem sua própria lógica e não passa de um ato primário de etnocentrismo tentar transferir a lógica de um sistema para outro" (Laraia, 2002, p. 87), pois a tendência mais comum é considerar lógico e racional somente os valores do seu próprio sistema, atribuindo aos demais um alto grau de irracionalidade, justificando certa hierarquia através da desqualificação do outro.

Todavia, realizaremos a nossa análise sobre as narrativas acerca da Nova Ordem Mundial, dentre outros discursos construídos pelos tributários das novíssimas direitas conservadoras brasileiras, a partir dos textos de Olavo de Carvalho (2012; 2014; 2018), Mario Ferreira dos Santos (2012) e Alexandre Costa (2015), assim como por meio de narrativas construídas por certos digital influencers que são veementemente influenciados por estes autores, apresentando algumas ponderações sobre a utilização de elementos da pós-verdade encontrada tanto nos sites destes grupos que se reconhecem como de direita e que tiveram algumas páginas retiradas do ar pelo facebook ${ }^{5}$ justamente por terem sido acusadas de produzir e difundir fake news, como também iniciaremos a nossa análise a partir de elementos trazidos no debate eleitoral dos presidenciáveis no Brasil em 2018.

Também é importante mencionar que a narrativa acerca da chamada Nova Ordem Mundial não foi construída no Brasil por Olavo de Carvalho, mas por grupos

5 Disponível Disponível em: $<$ https://noticias.uol.com.br/politica/eleicoes/2018/noticias/reuters/2018/07/25/facebookretira-do-ar-rede-de-fake-news-ligada-ao-mbl-antes-dizem-fontes.htm>. Acesso em: 24/08/ 2018. 
cristãos dos Estados Unidos, tendo como marco os escritos apresentados pelo televangelista estadunidense Pat Robertson (1991) através de seu livro intitulado "The New World Order", publicado em 1991, que descrevia um cenário em que os economistas de Wall Street, Federal Reserve System, Council on Foreign Relations, Clube Bilderberg e a Comissão Trilateral eram os gerenciadores de um fluxo de eventos que direcionavam as pessoas para um governo mundial supostamente destinado a enfatizar o Anticristo.

Essas supostas teorias não nasceram especificamente no final do século $\mathrm{XX}$, mas no século XIX por meio de narrativas milenaristas apocalípticas iniciadas com John Nelson Darby, dentre outros, que acreditavam em uma conspiração globalista que visava impor essa Nova Ordem Mundial tirânica como forma de cumprir as profecias sobre o fim dos dias encontrados na Bíblia a partir dos livros de Ezequiel, Daniel, evangelhos sinópticos, assim como no livro apocalipse. Contudo, essas narrativas foram utilizadas pelo candidato à presidência do Brasil, Cabo Daciolo (Patriotas), que se reconhece como evangélico, já no primeiro debate à presidência da república do brasil, em 2018.

\section{O caso Ursal no limiar da pós-verdade}

No dia 09 de agosto de 2018 foi realizado pela Rede Bandeirantes de televisão, também conhecida como Band, o primeiro debate entre os candidatos à presidência da república do Brasil ${ }^{6}$. No entanto, um dos pontos mais polêmicos discutidos naquela ocasião se deu através de um questionamento proferido pelo candidato à presidência Cabo Daciolo (Patriota) a outro presidenciável, Ciro Gomes (Partido Democrático Trabalhista - PDT), que acabou sendo acusado não apenas de pertencer a uma organização internacional secreta que estaria conspirando pela articulação e implementação de uma suposta ditadura comunista que integraria os países latinoamericanos por meio da chamada Ursal - União das Repúblicas Socialistas da América Latina, como também foi apontado como um dos fundadores do chamado Foro de São

\footnotetext{
${ }^{6}$ Disponível em: 〈https://www.youtube.com/watch?v=9EnJeUKwX_c〉. Acesso em: 11/08/ 2018. 
Paulo $^{7}$, organização criada em 1990 que visaria uma articulação latino-americana de partidos de esquerda que, no Brasil, está composto pelos seguintes partidos: Partido Democrático Trabalhista - PDT, Partido Comunista do Brasil - PC do B, Partido Comunista Brasileiro - PCB, Partido Pátria Livre, Partido Popular Socialista - PPS, Partido Socialista Brasileiro - PSB e Partido dos Trabalhadores - PT $^{\mathbf{8}}$.

Não obstante, antes de realizarmos uma breve análise sobre a polêmica neste debate demarcado pela pós-verdade é importante destacar que o Foro de São Paulo não deveria ser entendido como uma novidade ou como um problema do ponto de vista de suas articulações políticas à esquerda justamente porque antes dele existiram muitas outras organizações que também visavam um alcance internacional - tanto de esquerda quanto de direita - com este mesmo propósito de ampliar o seu contorno em busca de hegemonia, a exemplo dos diferentes momentos políticos vividos na chamada Associação Internacional dos Trabalhadores - AIT, iniciada no século XIX, que contou com a participação de anarquistas, comunistas e socialistas das mais distintas tradições, conforme mostramos em artigo sobre as divergência entre Karl Marx e Mikhail Bakunin na I Associação Internacional dos Trabalhadores (Rosa, 2004). Do mesmo modo, podemos encontrar outros exemplos mais à direita através do reconhecimento da articulação tanto da sociedade Mont Pelerin quanto do próprio Fórum Econômico Mundial, no século XX, que são organizações internacionais fundamentadas e forjadas a partir de um viés neoliberal que, no limite, visa a redução e até mesmo a eliminação do Estado, enfatizando as supostas benesses decorrentes de uma sociedade baseada no livre mercado, conforme também mostramos em artigo acerca das políticas de controle sobre as drogas no contexto neoliberal (Rosa, 2009).

Contudo, foi em meio ao debate eleitoral mencionado que vimos surgir uma questão um tanto quanto polêmica trazida pelo candidato Cabo Daciolo (Patriota) que não apenas considerou a existência da suposta Ursal, fundamentada em interpretações situadas a partir de leituras abalizadas naquilo que Olavo de Carvalho (2012; 2014;

\footnotetext{
${ }^{7}$ Disponível em: <http://forodesaopaulo.org/>. Acesso em: 13/0 2018.

${ }^{8}$ Disponível em: <http://forodesaopaulo.org/partidos/>. Acesso em: 11/08/ 2018.
} 
2018) tem chamado de Nova Ordem Mundial e globalismo, como fez a seguinte pergunta ao outro presidenciável:

\begin{abstract}
Ciro, o senhor é um dos fundadores do Foro de São Paulo. O senhor pode falar aqui para a população brasileira, para a nação brasileira, sobre o plano Ursal? O que o senhor tem para dizer sobre o plano Ursal, União da República Socialista Latino Americana? Tem algo para dizer à nação brasileira? ${ }^{9}$
\end{abstract}

O candidato questionado responde com certa perplexidade, tendo em vista que nunca havia ouvido falar dessa suposta Ursal, justamente porque essa organização jamais existiu: "Meu estimado Cabo, eu tive o prazer de lhe conhecer hoje e pelo visto o amigo também não me conhece. Eu não sei o que é isso. Não fui fundador do Foro de São Paulo. E acho que está respondido". O candidato presidenciável Cabo Daciolo protesta e ainda insiste, argumentando:

\begin{abstract}
Sabe sim. Sabe sim. Nós estamos falando aqui de um plano que chama-se Nova Ordem Mundial, união de toda a América do Sul, conexão de toda a América do Sul, tirando todas as fronteiras. Fazendo uma única nação. Pátria grande. Poucos ouviram falar disso e vai ser pouco divulgado isso. Eles sabem do que nós estamos falando. Quero deixar bem claro que no nosso governo o comunismo não vai ter vez. Vou deixar muito claro isso. E deixar muito claro também para os Estados Unidos e para a China. Infelizmente políticos de nossa nação estão dando a nossa nação. Mas, aqui também não vai mais ter vez. Eles vão disputar o segundo e terceira maior economia do mundo. Porque a nação brasileira no nosso governo vai ficar entre a primeira economia mundial para honra e glória do senhor Jesus Cristo".
\end{abstract}

A partir daquele momento pudemos verificar a emergência de uma das questões mais urgentes da nossa época acerca da fragilidade das fontes de informação que nos permite ponderar sobre qual seria o limiar entre a verdade e a chamada pós-verdade. Isso tudo porque o objeto da pergunta nunca existiu. Era um embuste que, em decorrência dessa condição, passou a ser polemizado e ridicularizado através de

\footnotetext{
${ }^{9}$ Disponível em: <https://www.youtube.com/watch?v=7ANqSdWvTlo $>$. Acesso em: 13/08/ 2018.
} 
memes ${ }^{10} \mathrm{e}$ até de músicas ${ }^{11}$ que circularam pela internet justamente porque o nome Ursal foi uma invenção criada ironicamente e utilizada pela primeira vez em 2001 pela professora Maria Lucia Victor Barbosa, como uma espécie de crítica ao Foro de São Paulo realizado em Havana naquele mesmo ano, uma vez que o ex-presidente do Brasil, Luiz Inácio Lula da Silva (Partido dos Trabalhadores - PT), havia feito um discurso naquele evento, questionando a Área de Livre Comércio das Américas ALCA $^{\mathbf{1 2}}$ e argumentando que o projeto em discussão visava anexar o Brasil e demais países signatários às demandas econômicas estabelecidas pelo governo estadunidense.

No entanto, segundo matéria publicada no jornal Folha de São Paulo no dia 13 de agosto de 2013, foi através do artigo intitulado "Os companheiros", publicado na internet no dia 9 de dezembro de 2001, que a professora universitária aposentada Maria Lucia Victor Barbosa apresentou pela primeira vez a palavra Ursal, questionando com certa ironia ${ }^{13}$ sobre "qual seria, me pergunto, essa tal integração no modelo CastroChávez-Lula? Quem sabe, a criação da União das Republiquetas Socialistas da América Latina (URSAL)?”. Não obstante, após ter sido procurada por várias pessoas e pela própria imprensa no intuito de esclarecer sobre essa suposta organização internacional, a professora Maria Lucia afirmou nesta matéria que "falava para as pessoas 'não passe isso' [adiante], mas não teve jeito, de repente espalhou".

Segundo essa mesma publicação, "Na internet, a referência mais antiga encontrada pela Folha para a Ursal é o artigo de Maria Lucia”. No entanto, no dia primeiro de maio de 2006, portanto, cinco anos após ter sido publicada esta matéria, a existência da Ursal aparece novamente, não mais como brincadeira, mas como fato verídico, sendo utilizada inclusive como prova cabal, como documento comprobatório de sua existência, em artigo publicado por Olavo de Carvalho no Jornal Diário do Comércio $^{\mathbf{1 4}}$. Contudo, é bastante provável que o discurso anti-comunista apresentado

${ }^{10}$ Disponível em: <https://www.youtube.com/watch?v=BCaAj4ugPQc >. A cessem: 13/08/ 2018.

11 Disponível em: <https://noticias.r7.com/prisma/coluna-do-fraga/a-ursal-nao-para-agora-tem-atesamba-16082018>. Acesso em: 13/08/2018.

${ }_{12}$ Disponível em: <http://www.camara.leg.br/mercosul/blocos/ALCA.htm>. Acesso em: 11/08/2018.

13 Disponível em: <https://www1.folha.uol.com.br/poder/2018/08/critica-do-pt-sociologa-diz-queinventou-ursal-em-2001-como-ironia.shtml>. Acesso em: 13/08/2018.

${ }^{14}$ Disponível em: <http://www.olavodecarvalho.org/os-inventores-do-mundo-futuro>. Acesso em: 13/08/ 2018. 
Revista NEP, Núcleo de Estudos Paranaenses, Curitiba, v.4, n.2, dez. 2018

por Cabo Daciolo esteja fundamentado nas aulas e escritos de Olavo de Carvalho $(2012 ; 2014 ; 2018)$ e isso pode ser encontrado em sua síntese acerca dos perigos desta tradição política à esquerda, uma vez que o autor afirma que "O projeto de governo mundial é originariamente comunista". (Carvalho, 2018, p. 166).

Embora Olavo de Carvalho tenha mencionado a suposta Ursal em seu texto cinco anos após a sua primeira alusão, insistindo em sua existência e nas presumidas provas cabais que supostamente a evidenciam, Maria Lucia, criadora da expressão que designaria essa presumida organização secreta, disse ter ficado perplexa ao ver sua piada sendo mencionada pelo presidenciável Cabo Daciolo no debate da Band: "Isso é meu, olha onde fui parar, eu fiquei boba”, afirma ${ }^{15}$. Portanto, será por meio deste episódio recente da política institucional brasileira que iniciaremos o nosso artigo, visando ponderar sobre as narrativas reproduzidas pelas novíssimas direitas conservadoras que se articulam, sobretudo por meio de canais da internet como o youtube, facebook, twiter, instagram, dentre outros, através de certos discursos construídos principalmente por Olavo de Carvalho tanto por meio de seus livros (Carvalho, 2012; 2014; 2018), quanto em seus vídeos e aulas ${ }^{\mathbf{1 6}}$.

A esses grupos conservadores orientados principalmente pela visão de mundo de Olavo de Carvalho e que passaram a se articularem por canais da internet, divulgando informações equivocadas, distorcidas ou mesmo sem uma fonte devida e que operam como digital influencers atuantes no campo das moralizações promovendo racismo de Estado em defesa da sociedade (Foucault, 2010), chamaremos de novíssimas direitas conservadoras. No entanto, essa atribuição conceitual ocorre porque estamos diante de uma grande novidade na história das civilizações, um fenômeno recente que altera radicalmente a forma como nos relacionamos com as informações.

Tudo isso ocorre principalmente porque deixamos de ser meros receptores de notícias selecionadas e difundidas, sobretudo, por grandes corporações privadas e gestoras dos meios de comunicação que operavam através de concessões estatais.

\footnotetext{
15 Disponível em: <https://www1.folha.uol.com.br/poder/2018/08/critica-do-pt-sociologa-diz-queinventou-ursal-em-2001-como-ironia.shtml >. Acesso em: 13/08/2018.

${ }_{16}$ Disponível em: <https://www.youtube.com/user/olavodeca>. Acesso em: 13/08/ 2018.
} 
Agora, em pleno século XXI, nos vemos diante da possibilidade de cada um de nós poder se transformar em uma espécie de canal de televisão e com a probabilidade ainda de ganhar dinheiro por meio dessa nova condição de homem-empresa ou de homo oeconomicus (Foucault, 2006). Basta encontrar a forma mais adequada para atingir o público selecionado através de um formato que consiga capturar aquele que está em busca de alguém que compartilhe com ideias próximas às suas, que um fato equivocado pode ganhar a força de verdade, dependendo da intensidade das visualizações, compartilhamentos e comentários encontrados nas páginas da internet.

Isso, concomitantemente, pode parecer algo muito bom e estranho em um primeiro momento, no entanto, é exatamente essa possibilidade de encontrar uma quantidade enorme de pessoas que pensem de uma maneira parecida ou de uma mesma forma, que permitiu a emergência daquilo que o dicionário Oxford trouxe como palavra do ano em 2016, a pós-verdade, ou seja, fazendo com que a difusão de uma informação sem uma fonte precisa ou mesmo distorcida e até mentirosa, tenha efeito de verdade em suas consequências. Assim, ao definir a pós-verdade como um adjetivo "relacionado a ou denotando circunstâncias em que fatos objetivos são menos influentes na formação da opinião pública do que os apelos à emoção e a crenças pessoais", o Dicionário Oxford ${ }^{\mathbf{1 7}}$ reconheceu que a partir de 2016 “a pós-verdade deixou de ser um termo periférico para ser um dos pilares dos comentários políticos, sendo agora muitas vezes usados por grandes publicações sem a necessidade de esclarecimento ou definição em suas manchetes".

Desse modo, a pergunta trazida por Cabo Daciolo ao também candidato Ciro Gomes (Partido Democrático Trabalhista - PDT) baseada em sua suposta participação conspiratória nesta organização internacional que existiria visando acabar com a cultura ocidental, conforme argumenta Olavo de Carvalho (Carvalho, 2012; 2018) acerca do que chama de globalismo e guerras culturais, não passou de uma invenção irônica trazida pela professora Maria Lucia, caricaturizando a conduta do ex-presidente Lula frente às determinações da ALCA através da proposição sarcástica daquilo que

\footnotetext{
17 Disponível em: <https://en.oxforddictionaries.com/word-of-the-year/word-of-the-year-2016> Acesso em: 13/08/ 2018.
} 
chamou provocativamente de Ursal. No entanto, embora a Ursal não exista, o Foro de São Paulo existe, porém, não possui a potência e todo esse poderio que presumem tanto o Daciolo quanto a sua referência, Olavo de Carvalho.

Também é importante mencionar que poucos dias após questionar o presidenciável Ciro Gomes acerca de sua participação tanto na Ursal quanto no Foro de São Paulo, o candidato evangélico Cabo Daciolo sobe o monte das Oliveiras atrás de orações e de jejum ${ }^{\mathbf{1 8}}$ e posta um vídeo na internet em que afirma que ${ }^{\mathbf{1 9}}$ :

\begin{abstract}
Já falei e vou repetir, Nova Ordem Mundial, Illuminati e maçonaria, chega. Chega, vocês vão sair da nação brasileira. A nação brasileira é do Senhor Jesus Cristo. Homens e mulheres que dobram de joelhos a Jesus. Eu tô no monte e nesse momento eu sei que tem muitos brasileiros na sua casa, no seu quarto, no seu monte de oração, no seu quarto de oração, clamando ao Senhor pela nação. Ei, essa Ordem Mundial tem um ciclo por vir e eles querem matança geral. Fechou mais um ciclo de setenta e eles vão tentar matar muitas pessoas pelo mundo. No Brasil vocês não vão entrar. Por que, Daciolo? Porque o Senhor, porque a palavra de Deus, é ele que coloca e é ele que tira o homem do poder. Quero revelar aqui que a estratégia que Deus nos deu é ficar nos montes orando. Por que Daciolo? Porque eles vão tentar me matar. Eles querem me matar. Mas, aqui não toca. Só com autorização divina. Eu tô a disposição dos senhores, só que só em cima dos montes. Lá embaixo, eles vão tentar me matar. Manda subir aqui pra ver se Deus não vai levar. Tenta pegar a gente aqui para ver se Deus não vai levar. Deixar muito claro, Nova Ordem Mundial, Illuminati e a maçonaria, saiam da nação brasileira.
\end{abstract}

Contudo, Olavo de Carvalho (2012; 2014; 2018), certamente o maior influenciador das novíssimas direitas conservadoras no Brasil, tem exercido uma autoridade enorme na política brasileira, principalmente no que se refere aos discursos produzidos sobre o processo de redemocratização do país nos anos 1980, alimentando um potente ódio aos islâmicos e, principalmente, socialistas e comunistas, assim como aos liberais que atuam junto ao sistema financeiro internacional, além dos illuminati e da maçonaria, conforme complementa o candidato presidenciável evangélico Cabo Daciolo (Patriotas). Basta verificar o número de inscritos não apenas no seu canal ${ }^{\mathbf{2 0}}$,

18 Disponível em: <https://www1.folha.uol.com.br/poder/2018/08/cabo-daciolo-sobe-a-monte-parajejuar-e-diz-tentarao-me-matar.shtml >. Acesso em: 31/08/ 2018.

${ }^{19}$ Disponível em: 〈https://www.youtube.com/watch?v=HxXXS7FED70>. Acesso em: 31/08/ 2018.

${ }^{20}$ Disponível em: <https://www.youtube.com/user/olavodeca $>$. Acesso em: 13/08/ 2018. 
mas também de boa parte de seus seguidores, a exemplo de Bernardo Kuster ${ }^{21}$, Nando Moura $^{22}$, Terça Livre ${ }^{23}$, Diogo Rox ${ }^{24}$, Spider $^{25}$, O antagonista ${ }^{26}$, dentre muitos outros, além das próprias narrativas históricas que defendem a Monarquia e que estão sendo construídas também por ele, a exemplo, os cursos do Brasil Paralelo ${ }^{27}$, que se fundamentam na ideia de que o Brasil vive sob a égide do socialismo e/ou comunismo desde a década de 1990. Além disso, é preciso mencionar que em 2017 foi realizado o lançamento do filme "O jardim das aflições" - título de um dos livros de Olavo de Carvalho - dirigido por Josias Teófilo ${ }^{28}$.

Também é importante destacar não apenas que o candidato à presidência da república deste eleitorado conservador é Jair Messias Bolsonaro (Partido Social Liberal - PSL), como o seu próprio filho, o deputado federal pelo Rio de Janeiro Eduardo Bolsonaro (Partido Social Liberal - PSL), já chegou a citar - no plenário da câmara dos deputados realizado no dia 06 de junho de 2018 - o livro intitulado "O mínimo que você precisa saber para não ser um idiota", mencionando que Olavo de Carvalho (2018), autor deste escrito, seria o maior filósofo brasileiro e que repudiava veementemente a homenagem feita à Karl $\operatorname{Marx}^{29}$ naquele mesmo dia. Inclusive, o deputado federal pelo Rio de Janeiro, Eduardo Bolsonaro, chegou a propor um alteração na redação da Lei no 7.716 , de 5 de janeiro de 1989 e da Lei no 13.260 , de 16 de março de 2016, visando criminalizar a apologia ao comunismo ${ }^{\mathbf{3 0}}$.

Assim, neste escrito, apresentaremos uma análise acerca de algumas das dimensões que orientam os discursos e narrativas do que estamos chamando de

\footnotetext{
${ }^{21}$ Disponível em: <https://www.youtube.com/watch?v=djPeP-8FYoE>. Acesso em: 13/02018.

${ }^{22}$ Disponível em: 〈https://www.youtube.com/watch?v=BeiBOMKWznE >. Acesso em: 13/08/ 2018.

23 Disponível em: <https://www.youtube.com/watch?v=6niDa27EV_s\&t=401s >. Acesso em: 13/08/2018.

${ }^{24}$ Disponível em: <https://www.youtube.com/watch?v=NzOSNKtHOek>. Acesso em: 13/08/2018.

${ }^{25}$ Disponível em: 〈https://www.youtube.com/watch?v=YyXAG2s6ZJY>. Acesso em: 19/08/ 2018.

${ }^{26}$ Disponível em: <https://www.youtube.com/watch?v=rr-GSoqff7g>. Acesso em: 19/08/ 2018.

27 Disponível em: 〈https://www.youtube.com/channel/UCKDjjeeBmdaiicey2nImISw>. Acesso em: 13/08/2018.

${ }^{28}$ Disponível em:< https://www.youtube.com/watch?v=9ejOM8 5S_s $>$. Acesso em: 19/08/ 2018.

${ }^{29}$ Disponível em: https://www.youtube.com/watch?v=NzOSNKtHOek acesso no dia 13 de agosto de 2018.
}

$30 \quad$ Disponível em: http://www.camara.gov.br/proposicoesWeb/fichadetramitacao?idProposicao=2085411 >. Acesso em: $13 / 08 / 2018$. 
novíssimas direitas conservadoras brasileiras, localizando-as a partir das aulas, vídeos e livros produzidos e divulgados pelo "professor Olavo de Carvalho" aos seus alunos que, assim como ele, defendem uma cosmologia ocidêntica, católica e conservadora, amparada na caricaturização de suas visões sobre a democracia ateniense, o direito romano e a tradição judaico-cristã que, segundo essa perspectiva etnocêntrica, teriam forjado todo o entendimento que fazemos acerca da civilização ocidental a partir de certa hierarquização de valores decorrente de sua própria perspectiva, na medida em que estes grupos inferiorizam e desqualificam os demais pontos de vista utilizados por outras sociedades que, inclusive, ameaçariam o próprio cristianismo, conforme argumentou Olavo de Carvalho no trecho do vídeo transcrito a seguir ${ }^{31}$ :

\begin{abstract}
Você também não se espante com isso porque esse negócio de anticristianismo no mundo, isso não é uma coisa passageira. Isso veio para ficar. E veio para piorar. Curiosamente, né? Nas empresas de mídia, né? O globo, a Folha, o New York Times, o Washington Post, eles raramente noticiam, né? Embora a comunidade cristã seja a mais perseguida do mundo notoriamente. Ora, agora, por exemplo, eu recebi este... Eu nem li ainda. Tenho ideia do que está dentro, mas nem li ainda. Chegou esse livro "By Their Blood: Christian Martyrs of the Twentieth Century", Mártires Cristãos do século vinte, James e Marti Hefley. Esse é um dos muitos livros a respeito... Também existe o livro do Robert Royal, "Catholic Martyrs of the Twentieth Century", Então você vendo isso, você vê que desde o término da Segunda Guerra, não há comunidade no mundo que seja mais perseguida, que sofra mais violência e mais morticídio do que os cristãos. São 150 mil cristãos que morrem por ano por motivo exclusivo da sua religião. E isso em tempo de paz. Não é guerra nenhuma. Então, isso aí, gente, veio para ficar. Então, enquanto você tem esse genocídio nos países islâmicos e comunistas. Aqui no ocidente, já começou o genocídio cultural que como todo mundo sabe é um preparativo do genocídio puro e simples. Quer dizer, primeiro você quebra a unidade e a honra da comunidade, né? Destruindo os seus símbolos, fazendo daquela comunidade objeto de ódio, tá certo? E depois, quando você os mata, ninguém mais percebe a diferença. Ninguém acha que isso tem nada demais. Isso veio para ficar. Não é brincadeira, tá certo?
\end{abstract}

É importante destacar que por cosmologia, cosmovisão ou mesmo visão de mundo, entendemos a maneira como pensamos que o universo ao nosso redor passa a ser organizado e como damos sentido às suas distintas disposições. Ou seja, quando garantimos que o mundo está conformado por entidades naturais, compostas por

${ }^{31}$ Disponível em: 〈https://www.youtube.com/watch?v=4Wc_Q2BTy_E〉. Acesso em: 27/08/ 2018. 
humanos e por objetos artificiais, enunciamos os princípios de uma cosmologia particular, isto é, mostramos no que se sustenta a nossa própria cosmologia, composta com os nossos próprios valores acerca das coisas que estão a nossa volta e, principalmente, o que pensamos sobre elas. Outros povos não estabelecem as mesmas distinções que nós, inclusive veem o mundo segundo outras perspectivas e, portanto, a partir de suas próprias cosmologias. Sendo assim, foi a nossa cosmologia que tornou possível a emergência e existência da ciência, entretanto, é necessário entender que essa cosmologia não é em si mesma o produto de uma atividade científica. A cosmologia, "é uma maneira de distribuir as entidades do mundo, ela é o fruto de uma certa época que permitiu que as ciências se desenvolvessem.” (Descola, 2016, p.48).

\section{Nova Ordem Mundial, globalismo e as guerras culturais}

Tudo aquilo que escapa ao entendimento desta suposta unidade cultural, que comporia aquilo que passou a ser chamado pelas novíssimas direitas conservadoras brasileiras de civilização ocidental, construída a partir do cristianismo, deve ser combatido no intuito de que seja garantida aquela suposta ordem que orientou as sociedades até o presente momento, evitando colocar em xeque novos valores que presumidamente comprometeriam sua existência e, portanto, sua cosmologia. É essa uma das principais premissas trazidas pela visão de mundo proposta por Olavo de Carvalho (2018) e seus seguidores a partir de sua leitura acerca dos valores cristãos encontrados, sobretudo na tradição escolástica, que teria construído tudo o que temos de bom hoje no planeta, já que "A falta de santos, de místicos e de filósofos num país de dimensões continentais e quinhentos anos de existência já basta para fazer dele uma anomalia espiritual assustadora, provavelmente sem similar na história universal." (Carvalho, 2018, p. 407).

Ao aderir uma crítica veemente a quaisquer formas de organização social que escapam ao modelo ocidental fundamentado, sobretudo no cristianismo e em seus valores, o autor ainda argumenta que "Um mito fundador não é um 'produto cultural', pela simples razão de que ele, e só ele, é a semente de toda a cultura possível.” 
(Carvalho, 2018, p. 408). Esses exageros etnocêntricos ainda podem ser localizados facilmente nos escritos de sua referência, Mario Ferreira dos Santos (2012), como também podemos encontrar no livro de seu aluno Alexandre Costa (2015), quando conclui que

\begin{abstract}
De tudo o que pesquisei nos últimos dez anos, mesmo quando inicialmente a trilha parecia levar a outro lugar, cheguei sempre a um único e mesmo ponto. Todos os artifícios utilizados para a implementação de uma nova civilização são também mecanismos para aprisionar as idéias cristãs dentro de estereótipos condenáveis pela nova cultura, que a cada dia conquista mais espaço. A Nova Ordem Mundial será, antes de tudo, anti-cristã. A espiral repressora que nos leva a esta sufocante realidade avança sem enfrentar resistência e utiliza de mecanismos como o politicamente correto, a moda e o medo. Ela é feita de constrangimento e isolamento crescentes que levarão, sem sombra de dúvida, a perseguições e condenações contra todos que defenderem as palavras e os exemplos de Nosso Senhor Jesus Cristo. (Costa, 2015, p. 147-149)
\end{abstract}

Provavelmente para um estudante de alguma área das ciências humanas, a visão trazida tanto pelo Cabo Daciolo (Patriotas) no debate eleitoral, quanto por Mario Ferreira dos Santos (2012), Olavo de Carvalho (2012; 2014; 2018) e seu aluno Alexandre Costa (2015) em seus escritos, seja facilmente situada a partir do que historicamente a antropologia social, em suas mais distintas tradições - à esquerda e à direita, se preferir - tem tratado como etnocentrismo, na medida em que os autores mencionados creem que a sua visão de mundo e, portanto, a sua cosmologia, estão corretas e as demais não apenas estão equivocadas, mas estão sendo construídas a partir de uma conspiração altamente organizada por três grandes grupos que compõem a Nova Ordem Mundial.

Como acreditamos que "As explicações encontradas pelos membros das diversas sociedades humanas, portanto, são lógicas e encontram a sua coerência dentro do sistema" (Laraia, 2002, p. 91), partiremos exclusivamente das análises destes autores e digital influencers, considerados pelas novíssimas direitas como extremamente importantes para a perpetuação de sua cosmologia, apresentando os principais elementos que orientam a sua racionalidade, conforme segue abaixo:

(...) as forças históricas que hoje disputam o poder no mundo articulam-se em três projetos de dominação global, que vou denominar provisoriamente "russo-chinês", "ocidental" (às vezes chamado erroneamente de angloamericano) e "islâmico". Cada um tem uma história bem documentada, 
Revista NEP, Núcleo de Estudos Paranaenses, Curitiba, v.4, n.2, dez. 2018

mostrando suas origens remotas, as transformações que sofreu ao longo do tempo e o estado atual da sua implementação. Os agentes que hoje os personificam são respectivamente: 1) A elite governante da Rússia e da China, especialmente os serviços secretos desses dois países. 2) A elite financeira ocidental, tal como representada especialmente no Clube Bilderberg, no Council on Foreign Relations (CFR) e na Comissão Trilateral. 3) Fraternidade Islâmica, as lideranças religiosas de vários países islâmicos e também alguns governos de países muçulmanos. Desses três agentes, só o primeiro pode ser concebido em termos estritamente geopolíticos, já que seus planos e ações correspondem a interesses nacionais e regionais bem definidos. O segundo, que está mais avançado na consecução de seus planos de governo mundial, coloca-se explicitamente acima de quaisquer interesses nacionais, inclusive os dos países onde se originou e que lhe servem de base de operações. No terceiro, eventuais conflitos de interesses entre os governos nacionais e o objetivo maior do Califado Universal acabam sempre resolvidos em favor deste último que embora só exista atualmente como ideal tem sua autoridade simbólica fundada em mandamentos corânicos que nenhum governo islâmico ousaria contrariar de frente. (Carvalho, 2012, p. 45-46).

Contudo, constatamos que a visão de mundo, cosmovisão ou mesmo cosmologia que orienta as novíssimas direitas conservadoras brasileiras, tenha sido construída a partir de leituras descobertas nos escritos de Mario Ferreira do Santos (2012), de quem o próprio Olavo de Carvalho reconhece ${ }^{32}$ ser "a maior criação da inteligência humana ao longo de toda a existência do Brasil". Entretanto, será exatamente por meio dessa sua grande referencia que encontramos certo comprometimento acerca de todas as suas análises do ponto de vista epistemológico, justamente porque o olhar apresentado se fundamenta naquilo que a antropologia social passou a chamar de etnocentrismo.

Esse conceito se fundamenta na ideia de que "cada cultura ordenou a seu modo o mundo que a circunscreve e que esta ordenação dá um sentido cultural à aparente confusão das coisas naturais" (Laraia,2002, p. 92). Assim, a nossa forma de enxergar o mundo geralmente está amparada em um olhar fundamentado nos nossos valores e não nos valores daquelas sociedades e culturas que estamos investigando. Apesar disso, o reconhecimento deste fenômeno por parte destes autores não é percebido por Mario Ferreira dos Santos (2012) e muito menos por Olavo de Carvalho (2014), já que ambos

\footnotetext{
${ }^{32}$ Disponível em: <https://www.youtube.com/watch?v=KQavHMAi61E >. Acesso em: 13/08/2018.
} 
tomam a sua visão de mundo não apenas como a mais adequada, mas como a única possível, conforme podemos encontrar na seguinte passagem:

\begin{abstract}
Outro aspecto que revela a barbarização é a floração crescente dos credos primitivos. As religiões dos ciclos culturais inferiores, a maneira primária de conceber a divindade, os rituais mais primitivos encontram campo livre, e apoio de multidões, e até de pessoas julgadas cultas. Em nosso país, tais fatos se multiplicam, em uma mistura de cristianismo, espiritismo, feitiçaria, umbandismo, e apresentam as formas mais bizarras. Na multidão, uma ambivalência entre Nossa Senhora e divindades pagãs é comum, quando se confundem e se identificam de tal modo que não se sabe mais se Nossa Senhora é Iemanjá ou Iemanjá é Nossa senhora. Um clero, em grande parte ignorante e indevidamente preparado, mal disposto para a ação pastoral, malogra a cada dia que passa. É preciso ter olhos de cego para não ver que o catolicismo, No Brasil, perde terreno numa progressão espantosa. (Santos, 2012, 43-44).
\end{abstract}

Nesse trecho, fica evidente como a leitura etnocêntrica deste autor tributário do pensamento conservador se apresenta em distintas dimensões, que vão desde o estabelecimento de uma suposta linha evolutiva através da atribuição da condição de "primitivos", "selvagens", "bárbaros" ou qualquer outra expressão desqualificadora que se apresenta frente aos "civilizados", que desde Franz Boas (2005) passou a ser questionada do ponto de vista de uma hierarquia entre indivíduos e culturas; até mesmo a adesão a determinada perspectiva que reivindica certa autoridade do ponto de vista do desenvolvimento humano e das religiões, assim como o entendimento da dimensão estática das culturas, tendo em vista que elas, ao contrário, são dinâmicas, já que "É praticamente impossível imaginar a existência de um sistema cultural que seja afetado apenas pela mudança interna" (Laraia, 2002, p. 96).

É por isso que a antropologia social nos chama a atenção para o relativismo cultural, argumentando que "Se todas as culturas merecem a mesma atenção e o mesmo interesse por parte do pesquisador, isto não leva a conclusão de que todas elas são socialmente reconhecidas como de mesmo valor. Não se pode passar de um princípio metodológico a um julgamento de valor." (Cuche, 1999, p. 144). Nesse sentido, o que vemos nas perspectivas de autores conservadores como Mario Ferreira dos Santos (2012), Olavo de Carvalho (2012; 2014; 2018) e Alexandre Costa (2015), a partir da citação anterior, é justamente a atribuição de valores ao invés da utilização daquilo que Cuche (1999), dentre muitos outros, chamam de neutralidade ética, que em decorrência 
de sua ausência e através dos juízos de valor orientados por um viés exclusivamente cristão do ponto de vista religioso, acabam por comprometer a análise, tendo em vista a fragilidade metodológica e epistêmica trazida nestas abordagens que orientam o pensamento das novíssimas direitas conservadoras brasileiras.

Não obstante, é preciso entender que a leitura etnocêntrica trazida por Olavo de Carvalho $(2012 ; 2014 ; 2018)$ que, no limite, reitera aquilo que Foucault (2010) chamou de racismo de Estado, se difere, em certa medida, do racismo em sua dimensão exclusivamente racial, indo além desta perspectiva, na medida em que entendemos que, através dos temas do evolucionismo, "O racismo vai se desenvolver primo com a colonização, ou seja, com o genocídio colonizador (Foucault, 2010,p. 216).

\begin{abstract}
O aprofundamento da idéia antropológica de cultura leva igualmente a reexaminar a noção de etnocentrismo. Uma distorção de sentido se produziu quando a palavra, até então utilizada somente nas ciências sociais, caiu no uso comum. Cada vez mais, pelo abuso de linguagem, etnocentrismo se tornou sinônimo de racismo. O etnocentrismo então passou a ser condenado com o mesmo vigor que o racismo. Ora, o racismo, mais do que uma atitude é uma ideologia, baseada em pressupostos pseudocientíficos cuja origem pode ser datada historicamente [Simon, 1970] e que está longe de ser universal. O etnocentrismo, ao contrário, pode ser encontrado tanto nas sociedades "primitivas", que consideram geralmente os seus vizinhos como inferiores em humanidade quanto nas sociedades mais "modernas" que se julgam mais "civilizadas". (Cuche, 1999, p. 242)
\end{abstract}

Nesse sentido, o olhar trazido por Cuche (1999) na citação anterior, por LéviStrauss (1985) e Geertz (2004), nos permite compreender como as visões trazidas tanto por Santos (2012) quanto por Carvalho (2012; 2014; 2018) e Costa (2015) não apenas se fundamentam em certa caricaturização do passado, na medida em que acreditam que as suas interpretações históricas sejam fidedignas a esse saudoso lugar histórico, entendido como o espaço da segurança no que se refere ao ideal das condutas humanas, como também fomentam uma relação assimétrica que desqualifica aquelas culturas que não compartilham com os seus valores e visões de mundo, reiterando o que Foucault (2010) chamou de racismo de Estado.

Portanto, foi no final de sua aula intitulada "Em defesa da sociedade", realizada entre janeiro e março de 1976 no Còllege de France, que Foucault (2010) mostrou como aconteceu a passagem da guerra das raças, nascida no século XVIII, para o que chamou de racismo de Estado, retomando como fenômeno fundamental do 
século XIX por meio da investida do poder sobre o homem enquanto ser vivo, proporcionando uma espécie de estatização do biológico, conforme podemos encontrar tanto na experiência da Alemanhã nazista quanto do próprio socialismo soviético, a partir do que o autor chamou de biopolítica ${ }^{33}$.

É bastante óbvio reconhecer que o racismo não nasceu nessa época. Contudo, a particularidade do racismo de Estado se deu pelo fato de que o que o inseriu nos mecanismos do Estado foi a emergência deste biopoder não apenas legitimador, mas legalizador da morte daqueles que ameaçavam a normalidade da vida saudável da população, uma vez que o imperativo do extermínio só seria admissível se estivesse fundamentado na eliminação do perigo biológico, ao mesmo tempo em que fortalecesse a própria espécie ou raça. Nesse sentido, as idéias trazidas pelas novíssimas direitas conservadoras amparadas nos escritos de Olavo de Carvalho (2012; 2014; 2018) podem ser entendidas a partir desta perspectiva, uma vez que visam não apenas a desqualificação daqueles grupos, entendidos como inimigos justamente porque não compartilham uma mesma visão de mundo cristã, mas, sobretudo, o seu próprio extermínio.

\begin{abstract}
Qualquer homem se pode transformar em etnógrafo e ir partilhar no local a existência de uma sociedade que o interesse: pelo contrário, mesmo que ele se transforme num historiador ou arqueólogo, nunca poderia entrar em contato direto com uma civilização desaparecida; só o poderá fazer através dos documentos escritos ou dos monumentos figurados que esta sociedade - ou outras - tiverem deixado a seu respeito. Enfim, não devemos esquecer que as sociedades contemporâneas que continuam a ignorar a escrita, aquelas a que nós chamamos "selvagens" ou "primitivas", foram, também elas, precedidas por outras formas, cujo conhecimento é praticamente impossível, mesmo de maneira indireta; um inventário consciencioso deverá reservar-lhes um número de casas em branco infinitamente mais elevado do que aquele em que nos sentimos capazes de inscrever qualquer coisa. Impõe-se uma primeira constatação: a diversidade de culturas é de fato no presente, e também de direito no passado, muito maior e mais rica que tudo o que estamos destinados a dela conhecer. (Lévi-Strauss, 1985, p. 49).
\end{abstract}

\footnotetext{
${ }^{33}$ Segundo Foucault (2010), essa nova tecnologia de poder chamada por ele de biopolítica seria um conjunto de procedimentos de controle, regulamentação e normalização decorrentes tanto das taxas de nascimentos e óbitos, quanto das taxas de reprodução e fecundidade da população, estabelecidas por certos processos que abarcam a natalidade e mortalidade tratando também da longevidade da vida que, a partir da segunda metade do século XVIII, passou a constituir uma série problemas econômicos e políticos seus primeiros alvos de controle.
} 
Não obstante, é importante esclarecer que estamos partindo de uma crítica ao pensamento do Olavo de Carvalho a partir de certas tradições das ciências sociais, sobretudo das perspectivas antropológicas trazidas por Lévi-Strauss (1985) e Geertz (2004), localizando o olhar etnocêntrico e mais especificamente cristocêntrico, ocidêntico e colonizador, para depois relacionarmos às práticas e cosmologias destas novíssimas direitas conservadoras a partir daquilo que Foucault (2010) chamou de racismo de Estado. Foi por isso que iniciamos nossa análise apresentando justamente o que propiciou a construção imaginativa do presidenciável Cabo Daciolo (Patriota), fundamentada nas hipóteses trazidas já há algumas décadas por Olavo de Carvalho (2012; 2014; 2018), acerca do que o autor tem chamado de Nova Ordem Mundial, globalismo e os seus reflexos através das chamadas guerras culturais.

Mas do que realmente se trata o globalismo e a Nova Ordem Mundial? Uma definição mais apressada poderia supor que são categorias que compõem uma teoria da conspiração elaborada por conservadores cristãos que procuram acusar os liberais estadunidenses de comunistas, que supostamente ameaçariam a cultura ocidental e, portanto, os valores que presumidamente orientam o nosso estilo de vida partindo de uma perspectiva anti-cristã e anti-cristo.

Contudo, certamente a narrativa mais interpretada no Brasil acerca dessas categorias pode ser encontrada não apenas na versão brasileira fundamentada nas ideias de Olavo de Carvalho $(2012 ; 2014 ; 2018)$, como pode ser apresentada pelo youtuber Luiz Camargo $V \log ^{34}$ que não apenas afirma ser conservador e eleitor do Bolsonaro ${ }^{35}$, como também reconhece "o professor Olavo" como o maior filósofo brasileiro. Segundo Luiz Camargo Vlog, a luta é contra o globalismo que seria um conceito ou estratégia que visaria transformar o mundo em uma espécie de nação única, com um único governo orientado por um mesmo arcabouço de leis, religião e, principalmente, uma única cultura, construindo, portanto, um ambiente ideal para que uma pequena

\footnotetext{
${ }^{34}$ Disponível em: 〈https://www.youtube.com/watch?v=xAJYd-k5zWw\&t=125s >. Acesso em: 30/08/ 2018

${ }^{35}$ Disponível em: 〈https://www.youtube.com/watch?v=Xb-fM9d2JhY〉. Acesso em: 30/08/ 2018.
} 
elite possa governar o planeta. Assim, o seu propósito único seria transformar toda a humanidade em escravos dessa pequena elite, sem criar a menor resistência diante desse processo.

Segundo Luiz Camargo Vlog, a interpretação feita acerca do anti-cristo, escrito no livro apocalipse da Bíblia, não se trata de uma pessoa especificamente ou de uma besta que governará o mundo, mas sim um sistema em que as pessoas se engajarão, conduzindo a humanidade a sua total desgraça. Todavia, esse sistema, que seria adornado por palavras como paz, ecologia, igualdade social, inclusão, tolerância, ou seja, expressões que ninguém ousaria questionar sob o risco de ser chamado de preconceituoso ou mesmo de fascista, receberia o nome de Nova Ordem Mundial. Nesse sentido, o maior obstáculo para a ascensão do globalismo seria, segundo ele, a cultura ocidental que, ao se sustentar pela tríplice moral judaico-cristã, direito romano e filosofia grega, precisaria ser totalmente desmantelada na medida em que seria suplantada por uma cultura global.

Seria exatamente essa tríplice associação que impediria qualquer reorganização ou mudança drástica na nossa civilização. Por isso, para que a Nova Ordem Mundial seja estabelecida sem maiores oposições, se faz necessário que esses três pilares sejam descontruídos e, paralelamente a isso, também seria necessário produzir um ambiente geopolítico adequado para a sua implementação. Luiz Camargo Vlog ainda elenca quatro fatores de preparação para que esse governo global seja possível. O primeiro, se daria pela suposta hegemonia da esquerda no poder político tanto dos partidos moderados quanto radicais, visto que o socialismo, influenciado pela Escola de Frankfurt, também visaria desmontar aqueles valores oriundos dessa tríplice que se faz presente na cultura ocidental.

O segundo fator elencado pelo digital influencer conservador seria justamente o que as novíssimas direitas de modo geral têm chamado de "politicamente correto", que seria uma espécie de tirania moral que não permitiria o questionamento daqueles conceitos supostamente propostos pelos globalistas. Já o terceiro, seria o sistema de economia metacapitalista, em que o governo comprometido com o globalismo não apenas apoiaria, mas também financiaria algumas empresas através da máquina pública, na medida em que essas empresas ascenderiam no cenário econômico, 
comprando outras empresas e assim criariam o monopólio. E, em contrapartida, financiariam a estadia inexaurível deste governo no poder. Assim, o metacapitalismo seria uma espécie de simbiose entre o Estado e a iniciativa privada. Inclusive, é por esse motivo que diversos grupos que compõem essas novíssimas direitas passaram a divulgar cartazes ${ }^{\mathbf{3 6}}$ com a frase "Olavo tem razão", associando a Operação Lava Jato ${ }^{\mathbf{3 7}}$ como um exemplo do diagnóstico metacapitalista, apresentado por Olavo de Carvalho (2018).

Por fim, temos o quarto e último fator que seria a elaboração e promoção das pautas progressistas que, através de recursos oriundos da agenda globalista bancada tanto por parte do governo quanto da iniciativa privada, financiariam militantes de movimentos sociais que lutariam em prol da legalização das drogas, descriminalização do aborto, casamento gay, multiculturalismo, facilidade de trânsito migratório entre países, cotas raciais, privilégios para minorias, fim da meritocracia, dentre muitas outras propostas amparadas no reconhecimento de direitos sociais, civis e políticos que são disseminadas pela mídia e pelos formadores de opinião visando construir uma sociedade mais justa. Desse modo, segundo Luiz Camargo Vlog, essas pautas são chamadas de progressistas justamente porque trazem propostas que se apresentam como uma espécie de progresso no "consciente coletivo", tratando como retrocesso tudo aquilo que for contrário a essas pautas.

Desse modo, o youtuber mencionado argumenta que, diante da ação conjunta desses fatores, dentre muitos outros que não foram mencionados, é possível verificar que esse cenário político, econômico, social, moral, cultural, etc. passou a ser paulatinamente desenhado para que seja possível implantar essa Nova Ordem Mundial. Assim, ao se questionar sobre quem seria essa elite que busca governar o mundo inteiro, Luiz Camargo Vlog responde que "Existem três forças históricas que disputam um projeto de domínio mundial: 1) o russo-chinês, chamado de eurasiano; 2) o ocidental, que são os chamados globalistas; 3) e o islâmico."

\footnotetext{
${ }^{36}$ Disponível em: $<$ https://olavodecarvalhofb.wordpress.com/2015/11/15/>. Acesso em: 30/08/ 2018 .

${ }^{37}$ Disponível em: 〈http://www.mpf.mp.br/para-o-cidadao/caso-lava-jato/entenda-o-caso $>$. Acesso em: 30/08/ 2018.
} 
No primeiro caso, visualiza-se um poder político e militar, que é a elite governante da Rússia e da China, em especial os seus serviços secretos; no segundo, presume-se a existência de um poder econômico, que seria a elite financeira ocidental, tal como representada no Clube Bilderberg, as famílias Rothschild e Rockefeller e, principalmente George Soros que, segundo Luiz Camargo Vlog, possuiria tentáculos em todos os setores do mundo contemporâneo; e, por fim, teríamos um poder religioso decorrente da fraternidade muçulmana, representada pelas lideranças religiosas de diversos países islâmicos. Assim, embora as concepções de poder global apresentadas a partir desses três agentes sejam bastante distintas entre si, uma vez que nascem de inspirações completamente heterogêneas; a competição e disputa, inclusive militar, são elementos recorrentes dessas forças, mesmo que suas fusões ocorram em determinadas dimensões, na medida em que os seus objetivos se fundamentam na destruição da cultura ocidental.

Apesar de, tanto o Cabo Daciolo quanto Olavo de Carvalo (2012; 2014; 2018) e demais autores conservadores defenderem uma atitude persecutória para com aqueles que ameaçam a existência da "velha ordem mundial", fundamentada em uma caricaturização do passado baseada em leituras equivocadas acerca da noção de cultura, tratada em termos estáticos, e a partir de certa visão estabelecida através da idéia de uma "alta cultura"; a noção de racismo de Estado, trazida por Foucault (2010), nos permite não apenas compreender como será "em defesa da sociedade" que os inimigos serão criados - globalistas, comunistas e islâmicos -, como o próprio entendimento de Olavo de Carvalho (2014,) que aproxima esse autor francês da esquerda, do socialismo e, portanto, daquilo que chamou de perspectiva euroasiana ${ }^{\mathbf{3 8}}$, se apresentando como um grande equívoco, conforme mostramos abaixo:

Solução final para as outras raças, suicídio absoluto da raça [alemã]. Era a
isso que levava essa mecânica inscrita no funcionamento do Estado
moderno. Apenas o nazismo, é claro, levou até o paradoxismo o jogo entre
o direito soberano de matar e os mecanismos do biopoder. Mas tal jogo está
efetivamente inscrito no funcionamento de todos os Estados capitalistas?
Pois bem, não é certo. Eu creio que justamente - mas essa seria uma outra
demonstração - o Estado socialista, o socialismo, é tão marcado de racismo

${ }^{38}$ Disponível em: <https://www.youtube.com/watch?v=ggM4rAL5NW A >. Acesso em: 27/08/ 2018. 
Revista NEP, Núcleo de Estudos Paranaenses, Curitiba, v.4, n.2, dez. 2018

quanto o funcionamento do Estado moderno, do Estado capitalista. Em face do racismo de Estado, que conformou nas condições de que lhes falei, constitui-se um social-racismo que não esperou a formação dos Estados socialistas para aparecer. O socialismo foi, logo de saída, no século XIX, um racismo. (Foucault, 2010, p. 219).

Certamente quando apresenta os três projetos de controle global sobre as condutas humanas, Olavo de Carvalho (2012; 2018) não apenas revela sua interpretação acerca dos possíveis conflitos que se encontram em busca de um projeto hegemônico de controle planetário, como mostra a sua perspectiva, a sua visão de mundo e, portanto, a sua cosmologia, fundamentada naquilo que entende como o mais correto e adequado não apenas ao Brasil, mas aos demais países.

Isso ocorre, sobretudo, a partir da sua construção amparada tanto em um modelo societário saudosista e caricaturizado, encontrado em um tempo um tanto quanto distante do nosso a partir de valores produzidos por certo entendimento distorcido sobre a democracia grega, o direito romano e a tradição judaico-cristã; como também presume a construção da condição de inimigo a todos aqueles que questionam a existência destes valores que supostamente permitiram a dominação daquilo que passamos a chamar recorrentemente de civilização, já que "A Bíblia, mito fundador da civilização ocidental, está no fundo de toda a nossa compreensão de nós mesmos e de todas as nossas possibilidades de ação." (Carvalho, 2018, p. 408).

No entanto, o trecho citado anteriormente nos permite compreender que o olhar deste autor acerca da noção de cultura se apresenta desatualizado, na medida em que mostra certo desconhecimento ou mesmo um não reconhecimento de que essa visão se encontra ultrapassada do ponto de vista das distintas tradições da antropologia social, campo do conhecimento científico que tem como objeto o estudo das diferentes culturas.

\begin{abstract}
A desconstrução da ideia de cultura subjacente aos primeiros usos do conceito, marcada por um certo essencialismo e pelo "mito das origens", supostamente puras, de toda cultura, foi uma etapa necessária e permitiu uma avança epistemológico. A dimensão relacional de todas as culturas pôde assim ser evidenciada. (Cuche, 1999, p. 238).
\end{abstract}

Tendo em vista que Olavo de Carvalho (2018) apresenta a sua visão acerca da noção de cultura fundamentada em uma perspectiva amparada na antropologia 
evolucionista, primeira tradição deste campo do conhecimento científico que nasce com a antropologia de gabinete de Edward Tylor, no século XIX, e que acreditava em uma escala unilinear do desenvolvimento e/ou evolução humana (Cuche, 1999); o seu entendimento se fundamentará na ideia de que tudo aquilo que ameaça certos valores, sobretudo, judaico-cristãos, que supostamente teriam permitido o nosso desenvolvimento enquanto seres humanos, deve ser entendido como algo atrasado, como um empecilho para o progresso, sendo, portanto, "primitivo", "selvagem", ou mesmo "bárbaro". Contudo, "O bárbaro é em primeiro lugar o homem que crê na barbárie" (Lévi-Strausss, 1985, p. 54).

Nesse sentido, é plausível compreender como o olhar etnocêntrico tanto de Olavo de Carvalho $(2012 ; 2103 ; 2014)$, quanto de Cabo Daciolo e demais youtubers que se apresentam como tributários daquilo que estamos chamando de novíssimas direitas conservadoras, possibilita não apenas localizar certo entendimento amparado em discursos conspiratórios, como permite produzir e/ou localizar possíveis inimigos - os "bárbaros" e "selvagens" da nossa época - que, ao questionar os pilares de suas interpretações históricas supostamente fidedignas, definem quem deverá ser combatido no intuito de garantir a permanência daqueles valores caricaturizados em um passado distante, mas que podem ser encontrados nas tradições ocidênticas, sobretudo no cristianismo, transformando, portanto, em inimigo aqueles que compartilham uma cosmologia distinta da sua. No entanto, o que ocorre é uma inversão e exagero de quem ameaça quem, conforme segue a narrativa abaixo:

Sejam comunistas, islâmicos ou bilionários, para implementar seus planos, não basta o poder sobre as instituições da nossa sociedade, é necessário destruir as instituições e o que estas simbolizam, é preciso inverter os valores e rebaixar a capacidade racional da maioria, corrompe-la com esmolas e desmoraliza-la com vulgaridades. Só com uma civilização destruída se pode implementar outra. O próprio David Rockefeller diz que a Nova Ordem Mundial vai emergir do caos. Pior: diz ele ainda que para a população aceitar a Nova Ordem Mundial, falta apenas a crise certa. O objetivo não declarado é a destruição da sociedade ocidental em que vivemos, baseada nos valores, crenças e costumes, que formaram nossas personalidades. Com todos os seus defeitos, a civilização que surgiu na Europa sobre as bases da moral cristã, do pensamento grego e do direito romano é a mais avançada, justa e próspera civilização que a história humana conheceu. A urgência em destruir os pilares da civilização ocidental, portanto, é apenas um desdobramento lógico do que está nos 
parágrafos anteriores. E quais são esses pilares? 1. A alta cultura, 2. A ordem jurídica, 3. O cristianismo. (Costa, 2015, p. 28-29).

Essa mesma narrativa etnocêntrica, que se enxerga a partir de uma lente persecutória e que, em decorrência disso, produz certo racismo de Estado (Foucault, 2010), foi construída por Olavo de Carvalho $(2012 ; 2014$; 2018) e passou a ser reproduzida veementemente por seus alunos, como Alexandre Costa (2015), podendo também ser encontrada em vídeos postados por seus discípulos, a exemplo do que ocorreu com o articulista do canal Terça Livre, Allan dos Santos, que inclusive chegou a entrevistar Olavo de Carvalho tendo como objeto de análise os Estados Unidos e a Nova Ordem Mundial ${ }^{39}$, apresentando - de uma maneira simplificada e bastante agressiva $^{\mathbf{4 0}}$ - uma espécie de resumo acerca deste assunto.

Contudo, é importante mencionar que, embora tenha diagnosticado essas três forças que se encontram em busca de hegemonia - comunistas, islâmicos e banqueiros -, Olavo de Carvalho (2012; 2014; 2018) não considera a pujança da qual se reconhece como tributário - o catolicismo - como outra dimensão destas lutas, justamente porque ele olha para esse campo a partir de sua visão etnocêntrica e, portanto, por meio de sua própria cosmologia ocidêntica e civilizatória, tributária do discurso do colonizador. É por isso que, antes de analisarmos a narrativa de Allan dos Santos, aluno de Olavo de Carvalho que possui um canal no youtube chamado Terça Livre, se faz necessário compreender que,

Se a cultura não é um dado, uma herança que se transmite imutável de geração em geração, é porque ela é uma produção histórica, isto é, uma construção que se inscreve na história das relações dos grupos sociais entre si. Para analisar um sistema cultural, é então necessário analisar a situação sócio-histórica que o produz como é. (Cuche, 1999, p. 143)

Assim, o vídeo apresentado de uma forma didática - porém agressiva - por Allan dos Santos no canal Terça Livre do youtube nos mostra não apenas uma espécie de síntese de sua leitura acerca de questões como a Nova Ordem Mundial, globalismo e suas consequências acerca das guerras culturais, como nos permite encontrar os

\footnotetext{
${ }^{39} \mathrm{https}: / /$ www.youtube.com/watch?v=6niDa27EV_s\&t=785s acesso no dia 24 de agosto de 2018.

${ }^{40} \mathrm{https} / / /$ www.youtube.com/watch?v=KQavHMAi61E acesso no dia 24 de agosto de 2018.
} 
principais inimigos construídos por essa narrativa e que podem, portanto, serem compreendidos como os novos "bárbaros" e "primitivos", a exemplo dos comunistas, islâmicos e bilionários, que supostamente deveriam ter sua existência erradicada da terra já que representam o mal, enquanto aqueles que os julgam se apresentam como representantes do bem. Neste vídeo disponibilizado no canal Terça Livre do youtube, que conta com mais de 375 mil visualizações ${ }^{\mathbf{4 1}}$, Allan dos Santos simplifica as análises de Olavo de Carvalho sobre estas questões, conforme segue:

O que nós chamamos de civilização, tá? Ci-vi-li-za-ção. Que foi da Europa para o mundo, foi construído numa base onde nós podemos colocar três pilares. Três pilares! Você pode dizer assim: Atenas, Roma e Jerusalém. Isso é o que nós chamamos de civilização. Por que? Daqui nós teremos a filosofia, tá? Eu vou botar a letra "F" em grego aqui. Filosofia! O direito romano, que depois ainda evoluiu bastante e teve um grande progresso e lá vai ser o ápice, inclusive, também da filosofia e, inclusive, também da moral, na escolástica, ou seja, na Idade Média. Resgate! Ah, lá vai esses conservadores falar de Idade Média. Oh mongoloide, quem manteve esses textos foram os cristãos porque os muçulmanos destruíram bibliotecas. Então, antes de você falar merda, né!? Eu não tô com muita paciência hoje não porque tem muito mongolóide abrindo a boca, aí. Esse Marcelo Farias aí, do instituto Liberal de São Paulo é uma besta. Um bicho burro, burro, burro mesmo. Eu não consigo nem imaginar que é má vontade ou que o cara é socialista. Não, não é não. O cara quer realmente o bem do país, mas é burro, burro que só ele. E aqui, a moral. A gente pode colocar aqui tanto... ou a cultura, vamos dizer assim. Moral, vamos entender melhor, para que fique claro: cultura judaico-cristã. Ah, Alan, se o ápice foi na Idade Média, por que não colocar apenas cristã? Não, porque nós também temos contribuições dos judeus. Muito bem, isso aqui é a civilização! Por mais que tenhamos ainda resquícios, né? - eu vou escrever filosofia aqui, caso alguém vá dizer depois que não entendeu, tá? Filosofia, tá? Vou separar aqui para que vocês possam entender bem. Não fique nada, não reste nenhuma dúvida, tá? Essa é a base do ocidente! É isso aqui o que reflete todo o progresso econômico, tecnológico, enfim, tudo o que hoje a gente pensa, usando o celular, a luz, etc. Tudo isso veio destas três correntes aqui. Essas três bases da civilização ocidental. Eu não coloquei ocidental aqui porque civilização é o ocidente. Não adianta. Se hoje, ah mas o Japão e não sei o que e tal... Tudo baseado daqui ó. Antes que essas três características saíssem da Europa não tinha civilização. Essa é a verdade. Pois bem, eles agora tão atacando isso aqui. Quem que ataca? Vamos lá. Ataca... Não sei se dá para ver o lado de cá. Deixa eu ver aqui. Só um minutinho. Dá para ver o outro extremo do quadro aqui, Então vou colocar aqui. Inimigos, i-nimi-gos. Os inimigos da civilização... Nós temos os globalistas, os comunistas e o islã. Sim, não adianta dizer que é o islã radical, não. É o islã mesmo. Ora interligados, ora brigando entre eles. Mas, esses aqui são... Aí os babacas vão dizer assim: o comunismo morreu, Alan. Caiu o muro de

41 Disponível em: <https://www.youtube.com/watch?v=uzNypn91U4U\&t=521s >. Acesso em: 24/08/2018. 
Revista NEP, Núcleo de Estudos Paranaenses, Curitiba, v.4, n.2, dez. 2018

Berlim. Tudo pensado! Nós não vamos falar aqui disso, né? Quem quiser depois, faça o curso lá do Terça Livre cursos e vai ter aula de história e vocês vão entender melhor isso. Quando a gente chegar em história moderna. Muito bem. E não sou eu o professor. Tem pessoas mais capacitadas para falar disso. Esses aqui [globalistas, comunistas e islã], eles são abertamente inimigos da filosofia, ou seja, da ratio, do uso da razão, que não é tomar partido e ideologia. Já expliquei para vocês que nós não temos que defender alguma coisa porque nós gostamos. Ah, porque eu gosto do Bolsonaro, por isso que eu vou defender. Não, eu defendo o Bolsonaro de maneira racional. Não é por gosto. Direito Romano que o ápice é na Idade Média. Isso aqui, eles são inimigos. Todos os três. Tanto os globalistas e os comunistas quanto o islã. Eles são inimigos. Aí com essa merda de direito... Uma das coisas que os liberais não entendem é a máxima maravilhosa, espetacular, que eles dizem que todas as ideias devem ter direitos políticos iguais. Porra, se todas as ideias tem direito... Olha aqui, atacando, né? Eles não entendendo o direito romano. Se eles tem direitos políticos iguais, porra, quem vai sobrar? Óbvio, os globalistas, os comunistas e o islamismo. Porque diante de alguém que acredita em democracia, que acredita em voto, que acredita em formação da sociedade, o que resta quando você coloca todas as ideias com direitos políticos iguais, o que sobra são os mais violentos, que estão aqui. Óbvio.

A partir desse trecho transcrito do vídeo do canal Terça Livre é possível verificar não apenas a fragilidade das análises essencialistas e etnocêntricas apresentadas por Allan dos Santos a partir de suas leituras conspiratórias decorrentes dos textos de Olavo de Carvalho (2012; 2014; 2018), como também constatamos um discurso reducionista que fomenta o ódio a determinados bilionários, comunistas e islâmicos sob a justificativa de que esses são os grupos que mais proferem o ódio no planeta, visando destruir a cultura ocidental, tratada pelo apresentador por meio de uma perspectiva estática, como se os valores que fundamentam a nossa sociedade fossem historicamente puros, na medida em que esses acusados devem ser tratados como os principais ameaçadores de suas cosmologias.

Ao argumentar que os seres humanos enxergam o mundo através da sua própria cultura, tendo, portanto, a propensão em considerar o seu modo de vida como o mais correto, adequado e natural, Laraia (2002) reconhece que o etnocentrismo em seus casos mais extremos seria um dos principais elementos responsáveis por numerosos conflitos sociais, na medida em que, ao considerar a sua cosmologia como a mais adequada, pode vir a fomentar não apenas o ódio contra aqueles grupos que possuem práticas, comportamentos e condutas diferentes dos seus julgadores, como também pode fomentar o extermínio destes através daquilo que Foucault (2010) chamou de 
racismo de Estado. Tudo isso pode ser encontrado nos discursos contra aqueles que supostamente comprometeriam os valores dessa "velha ordem mundial", a exemplo, da legalização do aborto e das drogas, do reconhecimento de direitos civis para pessoas que não se enquadram em certos modelos normativos, dentro outros muitos exemplos.

\begin{abstract}
O etnocentrismo, de fato, é um fenômeno universal. É comum a crença de que a própria sociedade é o centro da humanidade, ou mesmo a sua única expressão. A autodestruição de diferentes grupos refletem este ponto de vista. Os Cheyene, índios das planícies norte-americanas, se autodenominavam "os entes humanos"; os Akuáwa, grupo Tupi do sul do Pará, consideram-se "os homens"; os esquimós também se denominam "os homens"; da mesma forma que os Navajo se intitulam "o povo". Os australianos chamavam as roupas de "peles de fantasmas", pois não acreditavam que os ingleses fossem parte da humanidade; e nossos Xavantes acreditam que o seu território tribal está situado bem no centro do mundo. É comum assim a crença no povo eleito, predestinado por seres sobrenaturais para ser superior aos demais. Tais crenças contêm o germe do racismo, da intolerância e, frequentemente, são utilizadas para justificar a violência praticada contra os outros. (Laraia, 2002, p. 73).
\end{abstract}

Na transcrição do vídeo mencionado é possível constatar que Allan dos Santos não apenas reconhece como inimigo os tributários do islamismo, como argumenta que não há diferença alguma entre os muçulmanos de diferentes países e culturas, tendo em vista que, conforme argumentou Olavo de Carvalho (2012; 2014; 2018), essa religião seria fundamentada no ódio, enquanto que a sua visão cristã se fundamentaria no amor. Contudo, se procurarmos uma obra bastante conhecida do antropólogo estadunidense Clifford Geertz (2004), intitulada “Observando o Islã”, resultado de uma pesquisa etnográfica em que o autor vivenciou o islamismo em dois países distintos e, portanto, em dois contextos particulares; veremos que a narrativa proferida pelo representante do canal Terça Livre não passa de uma mera reprodução ainda mais vulgar e simplificada dos discursos equivocados de Olavo de Carvalho, utilizando como referência não apenas o conteúdo, mas também forma, já que a ofensa se faz presente nos vídeos de ambos os conservadores.

Ao desenvolver uma análise amparada no método etnográfico e, portanto, na observação participante, tratando do islamismo no Marrocos e na Indonésia, Clifford Geertz (2004) acabou constatando algo bastante diferente daquele discurso unitário acerca da cultura muçulmana nos distintos países, que tem sido proferido 
recorrentemente por Olavo de Carvalho (2012; 2014; 2018) em seus escritos. Contrariamente à abordagem conservadora amparada em meras especulações que negligenciam o método de pesquisa, o autor mostrou enormes diferenças entre países tributários da cultura islâmica, argumentando que "No Marrocos, a civilização foi construída com coragem; na Indonésia, com diligência. ”. (Geertz, 2004, p. 24).

Geertz (2004) parte da premissa de que não há possibilidade de generalizar o significante islamismo como se ele fosse o mesmo nas diferentes regiões do planeta, justamente porque esses países possuem trajetórias distintas, portanto, culturas diferenciadas, que tem os seus significados construídos a partir de suas particularidades históricas. Desse modo, ao argumentar que o islamismo seria a religião do ódio, as novíssimas direitas conservadoras acabam fomentando aquilo que Foucault (2010) chamou de racismo de Estado, tendo em vista a busca não apenas pela desqualificação deste outro "bárbaro", "primitivo" ou "selvagem", materializado na figura conspiratória dos globalistas do sistema financeiro, dos comunistas e islâmicos, que supostamente representariam a desordem e o caos, mas também buscam o seu extermínio.

\section{Considerações Finais}

Da mesma forma que a Ursal, mesmo sem nunca ter existido, foi utilizada como exemplo documentado desta suposta conspiração interacional chamada por Olavo de Carvalho $(2012 ; 2014 ; 2018)$ e demais defensores dessa perspectiva de Nova Ordem Mundial; as análises trazidas por Clifford Geertz (2004) em sua pesquisa etnográfica sobre os muçulmanos no Marrocos e na Indonésia também nos permitem mostrar essas fragilidades teóricas, metodológicas e epistemológicas principalmente no que se refere ao entendimento do autor acerca das diferenças culturais entre países que compartilham a crença no islamismo e que, portanto, vivenciam distintamente esse significante atribuindo diferentes significados a partir de suas particularidades históricas. No trecho a seguir, conseguimos localizar algumas das diferenças entre o islamismo nesses países: 
Revista NEP, Núcleo de Estudos Paranaenses, Curitiba, v.4, n.2, dez. 2018

\begin{abstract}
As estratégias gerias seguidas no Marrocos e na Indonésia durante o período pré-moderno para enfrentar esse dilema central - como trazer mentes exóticas para a comunidade islâmica sem trair a visão que a criou - foram, como já indiquei, notavelmente diferentes, em verdade quase diametralmente opostas; e o resultado disso é que as formas das crises religiosas que hoje suas populações enfrentam são até certo ponto imagens especulares. No Marrocos, a via desenvolvida foi de um rigor sem concessões. $\mathrm{O}$ fundamentalismo agressivo, uma tentativa atuante de impor uma ortodoxia sem jaça a uma população inteira, se tornou o tema central e meio às lutas. Isso não quer dizer que o esforço tenha tido sucesso uniforme, ou que o conceito de ortodoxia que surgiu seja necessariamente reconhecido como tal no resto do mundo islâmico. Mas, diferenciado e talvez errante como foi, o islamismo marroquino veio ao longo dos séculos a incorporar uma marcada pressão rumo ao perfeccionismo religioso e moral, uma determinação persistente para estabelecer um credo purificado, canônico e completamente uniforme numa situação superficialmente muito pouco promissora. O modo de ataque indonésio (e especialmente o javanês) foi, como disse, exatamente o contrário: adaptativo, absorvente, pragmático e gradual; uma questão de compromissos parciais, semi-acordos e puras e simples evasões. O islamismo que daí resultou nem mesmo pretendia a pureza, mas a amplitude; não a intensidade, mas a largueza de espírito. (Geertz, 2004, p. 29)
\end{abstract}

Ao analisar os textos, vídeos e aulas de Olavo de Carvalho é possível verificar que a construção supostamente teórica apresentada por ele se fundamenta exclusivamente em pesquisas que visam localizar determinados escritos que corroboraram as suas análises independente de sua veracidade. O que conta é a possibilidade de confirmar tudo aquilo que reitera a sua teoria conspiratória. Esse jogo pela verdade é bastante perceptível na medida em que passamos a acompanhar os representantes das novíssimas direitas brasileiras e, em especial, as conservadoras e liberal-conservadoras.

Certamente um dos grandes problemas decorrentes deste tipo de análise se dá justamente porque as referências utilizadas são instrumentalizadas no intuito de corroborar a conspiração. Assim, qualquer questionamento referente a alguma das dimensões apresentadas desta suposta teoria, faz com que o questionador torne-se parte do argumento conspiratório, impossibilitando, portanto, que o questionador se desvincule desta narrativa. Entretanto, o problema central deste tipo de análise é que ela simplifica de tal maneira a realidade que a polarização se torna a única possibilidade cosmológica e, portanto, a forma exclusiva de enxergar o mundo e mais, esse mundo passa a ser constituído de "nós" e "eles". Certamente para as novíssimas direitas conservadoras, "nós" somos as pessoas de bem, que trabalham, que seguem uma vida 
reta, cristã, dentro da lei e da ordem, dentre muitas outras características que, no limite, reiteram a condição de "civilizados"; enquanto "eles" são os esquerdistas, comunistas, anarquistas, índios, prostitutas, gays, drogados, defensores de bandidos e dos direitos humanos.

Assim, a análise que desenvolvemos acerca da importância da narrativa de Olavo de Carvalho para as novíssimas direitas de modo geral nos permite afirmar que boa parte de suas análises se fundamentam em informações equivocadas tendo em vista que partem de uma perspectiva epistemológica bastante desatualizada se considerarmos o campos científico da antropologia social, principalmente no que se refere à abordagem etnocêntrica que acaba resultando em uma conduta persecutória acerca de certos grupos sociais, a exemplo dos globalistas, comunistas e muçulmanos, mas quando são questionadas do ponto de vista de sua fragilidade documental, acabam se tornando parte dessa suposta conspiração.

Também é importante destacar que Olavo de Carvalho nem sempre erra totalmente acerca de suas ponderações, porém, acreditamos que ele não acerta na devida medida. Muitas vezes ele acerta no ponto, mas exagera justamente porque comete equívocos epistemológicos básicos, a exemplo de sua visão etnocêntrica que compromete todo o seu trabalho, tendo em vista que o autor confunde juízo de valor com juízo de fato, assim como cultura e metodologia. Contudo, se considerarmos a sua narrativa acerca do metacapitalismo, é possível reconhecer essa dimensão da financeirização da vida, conforme apontam outros autores de tradição marxista, embora tenham hibridizado suas análises também a partir de um viés pós-estruturalista, a exemplo de Maurizio Lazzarato (2017, p. 80) que argumenta que "no capitalismo e, em particular no capitalismo financeiro, a dívida é infinita, impagável e não expiável”, engendrando um nova técnica de governo populacional, visto por Olavo de Carvalho (2018) sob a ótica persecutória do globalismo.

Não obstante, é justamente por meio da adesão a essa leitura etnocêntrica encontrada nos textos de Mario Ferreira dos Santos (2012), Olavo de Carvalho (2012; 2014; 2018) e Alexandre Costa (2015), assim como os seus seguidores que atuam como digital influencers, que o olhar das novíssimas direitas conservadoras acerca do cristianismo também poderia ser tratado como uma outra dimensão globalista situada 
a partir de uma visão estática do ocidente, como se tudo aquilo que questionasse os seus supostos valores devesse ser combatido. Contudo, se analisarmos a articulação entre a indústria farmacêutica e a alimentícia, conforme mostramos em pesquisa publicada anteriormente (Azevedo; Rosa; Siqueira, 2018), podemos analisar de maneira mais aprofundada as distintas lutas pela hegemonia de certas dimensões do mercado no controle populacional, como exemplo a compra da Monsanto por parte da Bayer, retratada em um artigo publicado anteriormente.

Porém, o elemento mais importante que podemos encontrar nos discursos produzidos pelas novíssimas direitas conservadoras capitaneadas, sobretudo, pelos vídeos, aulas e escritos de Olavo de Carvalho (2012; 2014; 2018), se trata não apenas dos efeitos dessas visões de mundo que passaram a ocupar um lugar de destaque no debate eleitoral, mas principalmente do seu impacto enquanto verdade, mesmo sendo fake news. Assim, o problema por nós encontrado não se fundamenta especificamente no fato de que tanto os presidenciáveis Cabo Daciolo quanto Jair Bolsonaro compartilham da leitura conspiratória produzida por Olavo de Carvalho no Brasil, mas, principalmente, porque parte dos seus eleitores corroboram essa visão de mundo e, portanto, essa cosmologia que, no limite, visa exterminar aqueles que pensam de maneira contrária, ou seja, "A minoria tem que se curvar à maioria”, conforme afirmou publicamente Jair Bolsonaro ${ }^{\mathbf{4 2}}$, ao ameaçar um dos elementos centrais do liberalismo político, a saber, o Estado laico.

O youtuber Henry Bugalho fez uma breve análise sobre a relação entre o Cabo Daciolo (Patriotas), Jair Bolsonaro (Partido Social Liberal - PSL), Olavo de Carvalho e aquilo que estamos chamando de novíssimas direitas conservadoras, que resume em certa medida parte das nossas ponderações sobre o efeito desses discursos e, principalmente, desse tipo de cosmologia ocidêntica ${ }^{\mathbf{4 3}}$. Segundo ele, um dos grandes problemas trazidos por Olavo de Carvalho $(2012$; 2014; 2018) e sua teoria conspiratória importada a partir de escritos persecutórios estadunidenses não apenas para os católicos conservadores, mas, sobretudo, para os evangélicos que se apresentam como eleitores desses dois candidatos, se dá justamente porque ambos

\footnotetext{
${ }^{42} \mathrm{https}: / /$ www.youtube.com/watch?v=Zx0x4Q8qay4 acesso no dia 03 de setembro de 2018.

${ }^{43}$ https://www.youtube.com/watch?v=sfg5NwZ711M\&t=192s acesso no dia 03 de setembro de 2018.
} 
difundem uma visão intolerante contra aqueles que não creem nos seus valores, indo em direção contrária não apenas aos fundamentos do liberalismo político encontrados nos escritos de John Locke (2007), mas indo também contra alguns acordos internacionais dos quais o Brasil é signatário, a exemplo da Convenção Americana sobre Direitos Humanos, também conhecida como Pacto de San José da Costa Rica ${ }^{\mathbf{4 4}}$.

Para Henry Bugalho, é justamente essa mudança demográfica acerca do campo religioso que nos mostra a ascensão dos evangélicos como maioria religiosa no caso do Brasil, permitindo a difusão dos argumentos persecutórios produzidos por parte dos conservadores brasileiros. Segundo ele, "hoje o Cabo Daciolo (Patriotas) é o que melhor representa o brasileiro", justamente porque "o brasileiro hoje é fanático, uma boa parte, uma boa maioria dos brasileiros é fanática. Eles são incapazes de ver a realidade. Eles adoram uma teoria conspiratória. E isso você pode ver claramente nas redes sociais, no youtube, no WhatsApp. As pessoas adoram uma teoria conspiratória".

O youtuber mencionado, ainda argumenta que o Brasil se encaminha para um tipo de extremismo que não se dá apenas em um nível político e ideológico, conforme vimos emergir com as polarizações intensificadas desde junho de 2013, mas, sobretudo, um extremismo religioso. Se verificarmos os dados do IBGE acerca do perfil religioso brasileiro, verificaremos uma mudança vertiginosa dos evangélicos que ascendem visivelmente, tendo em vista que é a religião que mais cresce no Brasil. Assim, segundo o pesquisador do Instituto Brasileiro de Geografia e Estatística IBGE, José Eustáquio Diniz Alvez ${ }^{45}$, os dados do IBGE, Datafolha e Instituto PEW apontam para uma transição religiosa no Brasil, a partir da verificação de uma queda no número de católicos e um aumento dos evangélicos, assim como uma ascensão na pluralidade religiosa (queda do percentual de cristãos e aumento dos não cristãos). Contudo, a diferença constatada está na velocidade dessa transição, já que no caso do Datafolha, esse processo vai ocorrer de maneira mais rápida, com a inversão desta hegemonia, entre os dois grandes grupos, acontecendo no ano de 2028. Segundo

\footnotetext{
${ }^{44} \mathrm{http} / / /$ www.planalto.gov.br/ccivil_03/decreto/D0678.htm acesso no dia 03 de setembro de 2018.

45 Disponível em: <http://www.ihu.unisinos.br/186-noticias/noticias-2017/564083-a-transicaoreligiosa-em-ritmo-acelerado-no-brasil >. Acesso em: 03/09/ 2018.
} 
os dados do IBGE, o quadro religioso vai se alterar totalmente em um espaço de duas décadas, enquanto para o Datafolha a inversão vai ocorrer no curto lapso de cerca de uma década.

Henry Bugalho argumenta que os evangélicos atuam de maneira muito mais fervorosa, sendo muito mais fiéis aos princípios de suas doutrinas do que os católicos, tendendo a valorizar muito mais certos costumes como a família e a tradição. E em algumas vertentes, são muito mais extremistas, radicais e intolerantes que os católicos. Inclusive existem algumas dessas vertentes que falam mais do diabo do que de deus, além de serem comunidades muito mais fechadas, coesas e, sobretudo, intolerantes com o que está fora de sua cosmologia, agindo de maneira violenta contra umbandistas, muçulmanos e demais religiões que professam valores distintos dos seus. Assim, é justamente através dessa mudança paradigmática das religiões brasileiras verificada no cenário demográfico apresentado pelo IBGE que encontraremos seus impactos no campo político, vide o aumento da chamada bancada evangélica ou Frente Parlamentar Evangélica - FPE, que visam aumentar de 93 para 150 deputados federais e quintuplicar o número de senadores de 3 para $15^{\mathbf{4 6}}$.

É por isso que, segundo Bugalho, o Cabo Daciolo (Patriotas) seria um reflexo do cenário político brasileiro. Pois, mesmo tendo saído do Partido Socialismo e Liberdade - PSOL, esse presidenciável "é evangélico, ele fala como um pastor, ele defende certas teorias conspiratórias que surgiram em grupos cristãos norteamericanos. Essas teorias de illuminati, de Nova Ordem Mundial, essas teorias, sabe, do poder da maçonaria." Ele ainda argumenta que "são todas teorias que surgiram entre os cristãos norte-americanos e que foram agora reproduzidas no Brasil e que estão fazendo a cabeça dos evangélicos brasileiros. E não apenas dos evangélicos, mas também de muita gente". No entanto, é importante destacar que há diferenças enormes entre as visões de certos católicos e evangélicos no que se refere a essas teorias conspiratórias. Inclusive, Olavo de Carvalho, assim como o pastor Marco Feliciano, são críticos veementes do pastor Edir Macedo ${ }^{47}$, fundador da Igreja Universal do Reino

\footnotetext{
46 Disponível em: <https://www.valor.com.br/politica/5257923/evangelicos-querem-eleger-150deputados-e-15-senadores-este-ano $>$. Acesso em: 03/09/ 2018.

47 Disponível em: $<$ https://www.youtube.com/watch?v=JoQ_NEDFHa4 $>$. Acesso em: 03/09/ 2018.
} 
de Deus - IURD, justamente porque ele defende o planejamento familiar por meio da legalização do aborto ${ }^{48}$.

Segundo Bugalho, um dos indícios do futuro político do Brasil se dá justamente por meio da localização dessa reviravolta moral gerada por essa mudança paradigmática acerca do declínio do catolicismo e emergência dos evangélicos no país. “Isso é o que você vai ver daqui a 10, 15, 20 anos. É isso. São muitos cabos Daciolos dentro do congresso, dentro da política, dentro do senado, dentro das câmaras municipais, das prefeituras, dos governos, da presidência. Então, esse é o futuro do Brasil. Essa é a mudança de percepção do Brasil”.

O youtuber também destaca que isso foi possível, principalmente com a utilização da internet, pois "quando você pega ultra radicais direitistas defendendo certas teorias conspiratórias que confirmam essas noções ali, que o Cabo Daciolo, por exemplo, está dizendo, você está criando toda uma geração de jovens e adultos que vão acreditar nessas coisas". Assim, ao argumentar que esses "vão ser intolerantes contra as religiões, que vão ser intolerantes com o pensamento divergente também" Bugalho ainda afirma que Bolsonaro seria um tipo de hipócrita na medida em que "fala uma coisa e faz outra", enquanto que o "Cabo Daciolo é mais perigoso porque ele realmente acredita naquilo que ele diz. ".

Ao argumentar que "Bolsonaro surfou nessa onda", enquanto que o "Daciolo é essa onda", Bugalho se questiona: "Gente, mas eu não conheço ninguém parecido com esse cara?”. É exatamente aí que vemos os riscos não apenas da ascensão das novíssimas direitas conservadoras no Brasil por meio de seus discursos etnocêntricos que reiteram o que Foucault (2010) chamou de racismo de Estado, mas de uma nova maneira de lidar com a quantidade de informações que permitem a construção de verdades através de bolhas da realidade, independente de sua veracidade enquanto fato, gerando uma nova forma de construir os acontecimentos, que desde 2016 passamos a chamar de pós-verdade.

${ }^{48}$ Disponível em: 〈https://www.youtube.com/watch?v=blElwax2HyQ >. Acesso em: 03/09/ 2018. 


\section{Referências}

AZEVEDO, Elaine; ROSA, Pablo O.; SIQUEIRA, Marluce M. Drogas e alimentos (in)saudáveis no contexto da governamentalidade neoliberal. Revista Tomo. Programa de Pós-Graduação em Sociologia - PPGS. Universidade Federal do Sergipe - UFS. São Cristovão. N. 33. Jun-Dez. 2018. P. 147-192.

BOAS, Franz. Antropologia Cultural. Rio de Janeiro: Ed. Jorge Zahar, 2005.

CARVALHO, Olavo de. Três projetos de poder global em disputa. In: CARVALHO, Olavo de; DUGIN, Alexandre. Os EUA e a Nova Ordem Mundial: Um debate entre Alexandre Dugin e Olavo de Carvalho. Campinas: Vide Editorial, 2012.

CARVALHO, Olavo de. A nova era e a revolução cultural: Fritjof Capra \& Antonio Gramsci. Campinas: Vide Editorial, 2014.

CARVALHO, Olavo de. O mínimo que você precisa saber para não ser um idiota. Rio de Janeiro: Ed. Record, 2018.

COSTA, Alexandre. Introdução à Nova Ordem Mundial. Campinas: Vide Editorial, 2015.

CUCHE, Denys. A noção de cultura nas ciências sociais. Bauru: Ed. EDUSC, 1999.

D'ANCONA, Matthew. Pós-Verdade: A nova guerra contra os fatos em tempos de fake News. São Paulo: Faro Editorial, 2018.

DAY, Richard J. F. Gramsci is dead: anarchist currents in the newest social movements. Londres: Pluto Press, 2005.

DAY, Richard J. F. De la hegemonía a la afinidad: Solidariedad y responsabilidad en los nuevos movimientos sociales. Madrid: Enclave de Libros, 2016.

DELEUZE, Gilles. Nietzsche e a filosofia. São Paulo: Ed. N-1, 2018.

DESCOLA, Phillipe. Outras naturezas, outras culturas. São Paulo: Ed. 34, 2016.

FERNANDES, Estevão R. "Existe índio gay": A colonização das sexualidades indígenas no Brasil. Curitiba: Ed. Prismas, 2017.

FOUCAULT, Michel. Nascimento da biopolítica. São Paulo: Ed. Martins Fontes, 2006.

FOUCAULT, Michel. Em defesa da sociedade. São Paulo: Ed. Martins Fontes, 2010. 
NE P Revista NEP, Núcleo de Estudos Paranaenses, Curitiba, v.4, n.2, dez. 2018

GEERTZ, Clifford. Observando o Islã: O desenvolvimento religioso no Marrocos e na Indonésia. Rio de Janeiro: Ed. Jorge Zahar, 2004.

GRAEBER, David. Dívida: Os primeiros 5.000 anos. São Paulo: Ed. Três Estrelas, 2016.

LARAIA, Roque de B. Cultura: Um conceito antropológico. Rio de Janeiro: Jorge Zahar Editor, 2002.

LAZZARATO, Maurizio. O governo do homem endividado. São Paulo: Ed. N-1, 2017.

LÉVI-STRAUSS, Claude. Lévi-Strauss. (Coleção Os Pensadores). São Paulo: Ed. Abril Cultural, 1985.

LOCKE, John. Carta sobre a tolerância. São Paulo: Ed. Hedra, 2007.

NIETZSCHE, Friedrich. Genealogia da moral. São Paulo: Ed. Companhia das letras, 2009.

PIERUCCI, Antônio Flávio. Ciladas da diferença. São Paulo: Ed. 34, 2000.

ROBERTSON, Pat. The New World Order. Dallas: Word Publishing, 1991.

ROSA, Pablo O. As divergências entre Marx e Bakunin na I Associação Internacional dos Trabalhadores. Revista Mosaico Social: Revista do Curso de Graduação em Ciências Sociais - UFSC. Universidade Federal de Santa Catarina - UFSC. Florianópolis/SC. Ano 02. n. 02, dez. 2004.

ROSA, Pablo O. Políticas criminais de drogas e globalização econômica. In Seminário Nacional de Sociologia \& Política. GT 04 - Cidadania, controle social e migrações internacionais. Universidade Federal do Paraná - UFPR. Curitiba, 2009. Disponível em: $\quad<$ http://www.humanas.ufpr.br/site/evento/SociologiaPolitica/GTsONLINE/GT4/EixoIII/politicas-criminais-drogas-Pablo-Ornelas-Rosa.pdf>. Acesso em: 30/08/2018.

SANTOS, Mario Ferreira dos. Invasão vertical dos bárbaros. São Paulo: Ed. É Realizações, 2012.

TAYLOR, Fraser. Developments in the theory and pratice of cybercartography. Oxford: Elsevier Science, 2014.

Recebido: 10 set. 2018

Aceito: 16 nov. 2018 